\title{
New fossil genus and new extant species of diatoms (Stephanodiscaceae, Bacillariophyceae) from Pleistocene sediments in the Neotropics (Guatemala, Central America): adaptation to a changing environment?
}

\author{
Christine PAILLÈS ${ }^{1, *}$, Florence SYLVESTRE ${ }^{2}$, Alain TONETTO ${ }^{3}$, \\ Jean-Charles MAZUR ${ }^{4} \&$ Sandrine CONROD $^{5}$ \\ ${ }^{1,2,4,5}$ Aix-Marseille Université, CNRS, IRD, Collège de France, INRAE, CEREGE, \\ 13545 Aix-en-Provence cedex 4, France. \\ ${ }^{3}$ Aix-Marseille Université, Fédération de Chimie, PRATIM, 3 Place Victor Hugo, \\ 13331 Marseille Cedex 3, France. \\ *Corresponding author: pailles@cerege.fr \\ 2Email: sylvestre@cerege.fr \\ ${ }^{3}$ Email: alain.tonetto@univ-amu.fr \\ ${ }^{4}$ Email: mazur@cerege.fr \\ 5Email: conrod@cerege.fr
}

\begin{abstract}
Several taxa of Stephanodiscaceae were found in the upper section of Pleistocene sediments from Lake Petén-Itzá (Guatemala). A new fossil genus Cyclocostis Paillès gen. nov. and new extant species Discostella gabinii Paillès \& Sylvestre sp. nov. are described. Cyclocostis gen. nov. is characterized by a strongly tangentially undulated valve surface, coarse unequal striation reaching a central punctum in the valve center, an absence of central lamina and domed criba, widely open alveoli with one median recessed costa bearing marginal fultoportulae and a single rimoportula all within a ring. A single valve face fultoportula is present on the raised part of the valve opposite the rimoportula. Differences relative to similar genera and the delimitation of a new genus are discussed. Discostella gabinii sp. nov. is distinguished by circular and flat valves, a small central area bearing 5 to $>30$ scattered large areolae giving a colliculate appearance, medium-sized alveoli, marginal fultoportulae on every $4-5^{\text {th }}$ costa, a single rimoportula and internally smooth valve center. Differences to similar taxa in the genus Discostella are discussed. The succession of the species of Cyclotella, Discostella and Cyclocostis gen. nov. in our record could represent eco-phenotypic responses to particular environmental stress/change.
\end{abstract}

Keywords. Diatom, Stephanodiscaceae, genus, Cyclocostis rolfii, Discostella gabinii, Pleistocene, Guatemala.

Paillès C., Sylvestre F., Tonetto A., Mazur J.-C. \& Conrod S. 2020. New fossil genus and new extant species of diatoms (Stephanodiscaceae, Bacillariophyceae) from Pleistocene sediments in the Neotropics (Guatemala, Central America): adaptation to a changing environment? European Journal of Taxonomy 726: 1-23. https://doi.org/10.5852/ejt.2020.726.1169 


\section{Introduction}

Publications describing freshwater diatoms from Central America are scarce. If few paleolimnological studies based on diatoms have been conducted in Costa Rica (e.g., Chávez \& Haberyan 1996; Haberyan \& Horn 1999, 2005), Nicaragua (e.g., Slate et al. 2013) and Panama (e.g., Temoltzin-Loranca et al. 2018), even fewer have been conducted in the Yucatan Peninsula, and these are generally limited to the Holocene (Whitmore et al. 1996; Rosenmeier et al. 2004). Longer diatom records originated from the Mexico Basin (Bradbury 2000; Ortega et al. 2010). Only the record of Cohuo et al. (2018) is based on the same sedimentary sequence as the present study. Furthermore, since the majority of fresh water bodies in this region are alkaline, calcium-bicarbonate dominated systems (Pérez et al. 2013), valve preservation is usually poor (Metcalfe et al. 2000). A few taxonomic studies have been recently published on diatom species from, e.g., Panama (Lange-Bertalot \& Metzeltin 2009) or El Salvador (Wetzel \& Ector 2014; Krahn et al. 2018), with one dealing with centric diatom species of Cyclotella (Kütz.) Bréb. from Guatemala (Paillès et al. 2018).

In the last 50 years, the genus Cyclotella (Brébisson 1838: 19) has received significant attention. There have been many attempts to classify species within the genus according to the morphological features by Lowe (1975), McFarland \& Collins (1978), Serieyssol (1981), Servant-Vildary (1986), Loginova (1990), Håkansson (1990), Håkansson et al. (1993) and Tanaka (2007). In a revision of the genus Cyclotella, Håkansson (2002) subdivided it on the basis of the type of undulation of the valve, the morphology of the central area, the position of the rimoportula, and the position and number of satellite pores of marginal fultoportulae. This author also suggested that the number of satellite pores of marginal fultoportulae may be the most important character for defining phylogenetic groups within Cyclotella. Interestingly, Loginova (1990) observed that only fossil species of Cyclotella have marginal fultoportulae with three satellite pores. Under Håkansson's (2002) assumption, Prasad \& Nienow (2006) identified one lineage of Cyclotella with three satellite pores and another with two satellite pores. Similarly, using the presence/absence of a central lamina (Servant-Vildary 1986) and the presence/absence of marginal chambers (Lange \& Syversten 1989), the authors identified three groups of Cyclotella. Khursevich \& Kociolek (2012) distinguished 11 groups of Cyclotella based on the structure of alveolae, the number and location of rimoportula, and the structure of striae. For Houk et al. (2010), the genus Cyclotella is subdivided into three groups. A revision of the classification of Cyclotella by Nakov et al. (2015) identified the position of the rimoportula as a synapomorphy. Cyclotella s. str. has a rimoportula located on a costa within the ring of marginal fultoportulae, as opposed to those of Discostella Houk \& Klee, Lindavia (F.Schütt) De Toni \& Forti and Paleotertiarius (Håk. \& Khursevich) S.Blanco (Nakov et al. 2015). Àcs et al. (2016) separated the genera Lindavia, Pantocsekiella K.T.Kiss \& Àcs and Edtheriotia Kociolek, You, Stepanek, R.L.Lowe \& Wang from the genus Cyclotella on the basis of morphological and genetic characters. At this point, these new concepts make it difficult to disentangle the phylogeny and taxonomy of this group.

In 2006, the Petén-Itzá Scientific Drilling Project (PISDP) recovered a total of 1327 m of sediment from seven sites in Lake Petén-Itzá, Petén, northern Guatemala, for paleoclimate and paleoenvironmental studies (Hodell et al. 2008). The fossil diatom flora of Lake Petén-Itzá was analyzed in core PI-6 dated by tephro-chronology and covering the last $84 \mathrm{ka}$ (Kutterolf et al. 2016). From this record, the new species Cyclotella petenensis Sylvestre, Paillès \& Escobar and C. cassandrae Paillès \& Sylvestre were described (Paillès et al. 2018). Based only on morphological observations, we herein describe a new genus belonging to the family Stephanodiscaceae Glezer \& Makarova, Cyclocostis Paillès gen. nov., and a new species of Discostella from the same core, bringing the total to three new species and one new genus described from the Pleistocene sediments of Lake Petén-Itzá. So far, except for C. cassandrae and the new genus Cyclocostis gen. nov. (described herein) that are absent from the modern dataset (Pérez et al. 2013), the majority of species in the fossil record are still extant and will therefore provide a solid basis for paleolimnological reconstructions. 
PAILLÈS C. et al., New fossil genus and new extant species of Stephanodiscaceae (Guatemala)

\section{Material and methods}

During the International Continental Scientific Drilling Program (ICDP) expedition PISDP in 2006, sediment cores were collected at site PI-6 in Lake Petén-Itzá (Hodell et al. 2008), providing a continuous record of sediment accumulation for the last $84 \mathrm{cal} \mathrm{ka}$. Cores were stored on board at $5^{\circ} \mathrm{C}$, then transferred to the Minneapolis Core-Repository in Minnesota (USA) where samples were taken from depths ranging between 0 and $70 \mathrm{mcd}$ (meter composite depth) at $10-\mathrm{cm}$ intervals. The core was dated by ${ }^{14} \mathrm{C}(44$ ages) on terrestrial remains and three tephra layers dated by $\operatorname{Ar} / \operatorname{Ar}$ (Escobar et al. 2012). An age model was derived using a weighted fit through 36 age-depth points. The sediments consisted of laminated light brown to greenish clays, gypsum and tephra layers (for more details see Hodell et al. 2008).

A $5 \mathrm{~mm}$ thick slice of sediment $(0.5 \mathrm{~g})$ was first decarbonated with hot $37 \% \mathrm{HCl}$ for a few hours, the organic matter was then oxidized with hot $33 \% \mathrm{H}_{2} \mathrm{O}_{2}$ for a few hours. Diatom suspensions were successively rinsed and decanted with distilled water. Aliquots of cleaned diatoms were diluted and evaporated at room temperature onto coverslips then mounted on glass slides using Naphrax ${ }^{\circledR}$ mounting medium. Diatom slides were examined under oil immersion using light microscopy (LM) at $630 \times$ or $1000 \times$ magnification using a Nikon Eclipse 80i microscope equipped with differential interference contrast optics and a Nikon D300 camera. Counting was generally performed on three slides. The total number of valves counted per sample varied from 200 in nearly sterile samples to $>1200$ in rich samples. Diatom identification and taxonomy followed Krammer \& Lange-Bertalot (1986, 1988, 1991a, 1991b) with the revised nomenclature in AlgaeBase (Guiry \& Guiry 2020). Number of striae in $10 \mu \mathrm{m}$ were determined following Genkal (1977), i.e., as the number of striae in $10 \mu \mathrm{m}$ of the valve circumference, not in $10 \mu \mathrm{m}$ of a transect (chord).

For scanning electron microscopy (SEM) observations, a few drops of cleaned diatom material were air-dried on circular coverslips which were then attached to aluminum stubs and gold-coated with Cressington 108 auto (Watford, UK). Diatoms were examined with a XL 30 ESEM Philips SEM at an accelerating voltage of $1-30 \mathrm{kV}$.

Taxonomic descriptions followed terminology given by Anonymous (1975), Ross et al. (1979), Theriot \& Serieyssol (1994), Håkansson (2002), Tanaka (2007), Houk et al. (2010, 2014) and Khursevich \& Kociolek (2012).
Abbreviations
$\mathrm{LM}=$ light microscopy
$\mathrm{mfp}=$ marginal fultoportula
$\mathrm{rm}=$ rimoportula
SEM $=$ scanning electron microscopy
vffp $=$ valve face fultoportula

\section{Results}

Sediments from core PI-6 revealed a rich and diverse diatom flora (153 species belonging to 42 genera). Ninety-six species are extant and were found in diverse waterbodies from the Yucatan Peninsula (Pérez et al. 2013). The upper part of the sedimentary sequence between 60-16 ka is characterized by an alternation of the species of Cyclotella and Discostella (Fig. 1): Cyclotella meneghiniana Kütz., C. petenensis, Discostella stelligera (Cleve \& Grunow) Houk \& Klee, C. caspia Grunow, C. cassandrae, a new species of Discostella, and what appears to be a new genus of Stephanodiscaceae. 


\title{
Taxonomic treatment
}

\author{
Division Bacillariophyta G.Karst. \\ Class Mediophyceae Medlin \& Kaczmarska \\ Order Thalassiosirales Glezer \& Makarova \\ Family Stephanodiscaceae Glezer \& Makarova
}

Genus Cyclocostis Paillès gen. nov.

\section{Type species}

Cyclocostis rolfii Paillès gen et sp. nov. (see below).

\section{Diagnosis}

A new morphotypic genus of Stephanodiscaceae. Cells solitary, circular in valve view. Marginal and central areas coarsely striated with branching striae merging in the middle of the valve into a central punctum. Central area strongly tangentially undulated, focus clear only on half the central area. Submarginal alveoli finely punctuated, transforming into radiating rows of large irregular areolae in the central area. Internally, alveoli delineated by thick elevated costae reaching the valve center to form a subcircular silica ring. Alveoli widely open with a median recessed costa bearing marginal fultoportulae. Central lamina absent. Single rimoportula within a ring of marginal fultoportulae reduced to a rounded tube tangentially orientated and born on a recessed costa. On the mantle, outer expressions of marginal fultoportulae and rimoportula consisting of simple rounded openings without projections. One single valve face fultoportula consisting of a central tube surrounded by three satellite pores that opens externally into a round opening on the raised part. Cingulum present consisting of an open valvocopula and several copulae.

\section{Etymology}

The genus name refers to the circular morphology of the valve and marked radiating costae.

Cyclocostis rolfii Paillès gen et sp. nov.

Figs $1-40$

\section{Etymology}

This species is named in honor of Rolf Klee for his dedicated career on Stephanodiscaceae.

\section{Type material}

\section{Holotype}

Slide PC0608731 and sediment PC0608728 deposited at the Laboratoire de Cryptogamie, Muséum national d'histoire naturelle (MNHN) Paris, France. Specimen on slide PC0608731 (Fig. 4) represents the holotype designated here.

\section{Isotype}

Slide ZU 11/30 and sediment R1284 deposited at the Friedrich Hustedt Diatom Center in Bremerhaven, Germany.

\section{Type locality}

GUATEMALA • Department of Petén, Lake Petén-Itzá; $16^{\circ} 15^{\prime} 50^{\prime \prime} \mathrm{N}, 89^{\circ} 15^{\prime} 00^{\prime \prime} \mathrm{W}$; lacustrine sediment in core PI-06; sample GLAD9-PET06-6B-10H1- 98-99 cm (27.83 m below lake floor) consisting of light gray carbonated sediment; core collected in February 2006. 
PAILLÈS C. et al., New fossil genus and new extant species of Stephanodiscaceae (Guatemala)

\section{Description}

Light microscopy (Figs 1-24)

In girdle view, cells quadrangular, displaying strongly undulated valve faces (Fig. 1). In valve view, frustules circular, 7-22 $\mu \mathrm{m}$ in diameter (Figs 2-24). Marginal area (outer $1 / 3$ of valve) concentrically undulated and consisting of an external ring of small bright 'chambers' transforming into strong radiating costae -10 to 12 striae in $10 \mu \mathrm{m}$. The central $2 / 3$ of valve surface strongly tangentially undulated, forming an S shape in large specimens (Figs 7-8). The central area with radial anastomosing striae of unequal

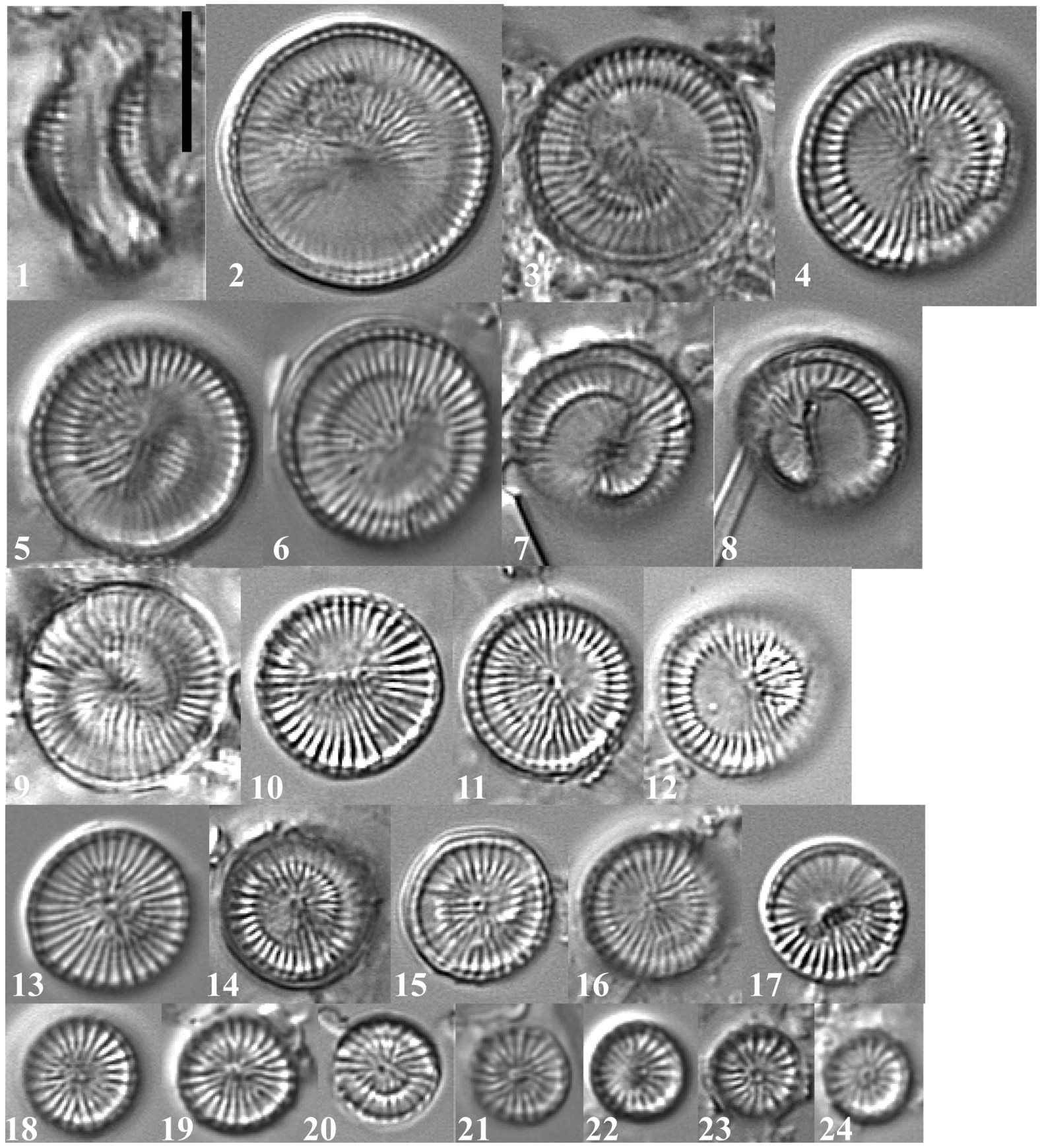

Figs 1-24. Type material of fossil lacustrine diatom Cyclocostis rolfii Paillès gen. et sp. nov., Lake PeténItzá (Guatemala); LM girdle view (1) and valve views (2-24). 4. Holotype (MNHN, slide PC0608731). 7-8. Valve surface strongly tangentially undulated, forming an $\mathrm{S}$ shape. Scale bar $=10 \mu \mathrm{m}$. 


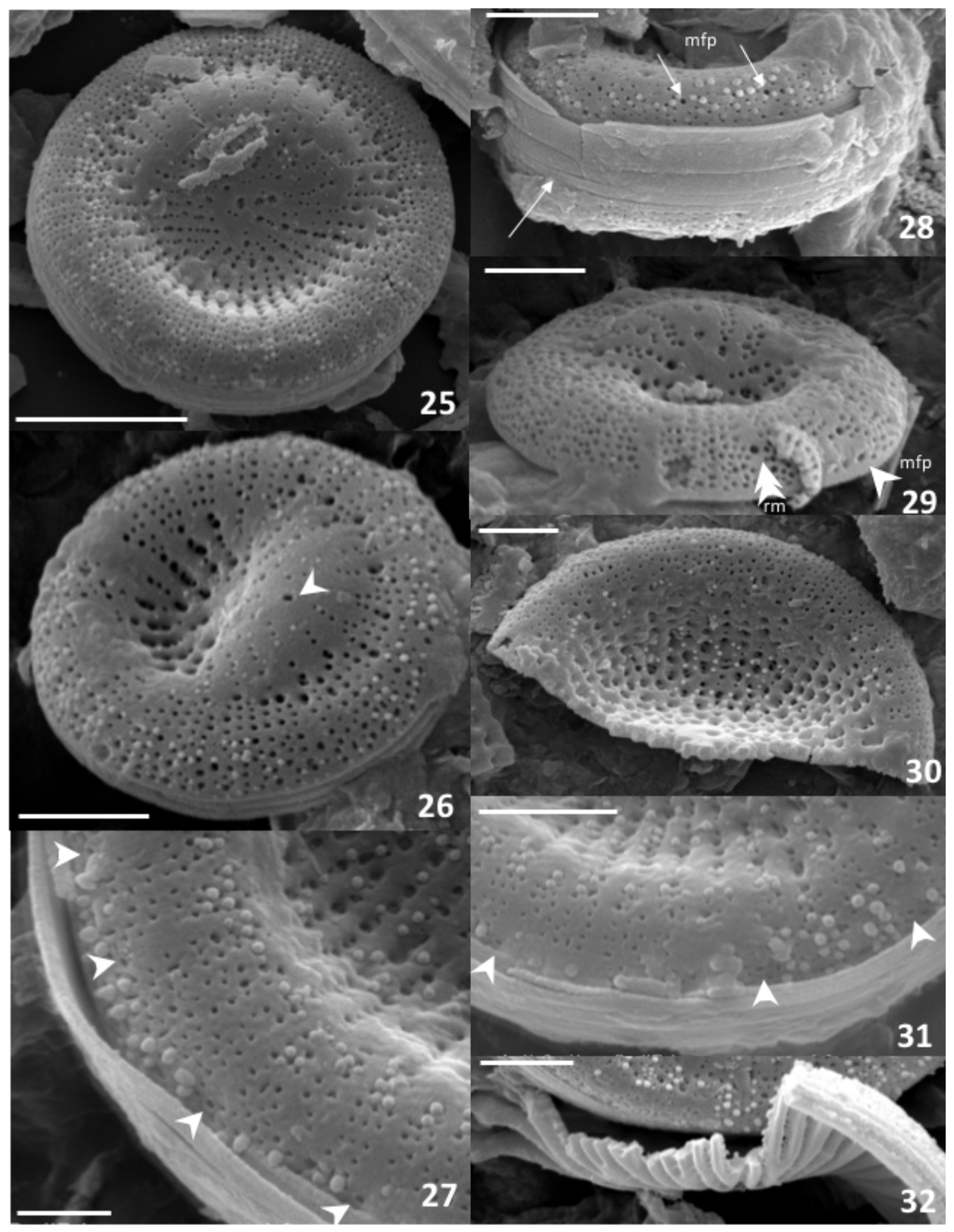

Figs 25-32. Type material of fossil lacustrine diatom Cyclocostis rolfii Paillès gen. et sp. nov.; SEM external valve views. 25. Valve view of concentrically undulated marginal area and tangentially undulated central area; punctuated striae become in the central area rows of larger areolae arranged in a stellate pattern. 26. Valve surface with scattered papillae; the external opening of the single valve face fultoportula is located on the raised part (white arrowhead). 27. Marginal area showing the external openings of marginal fultoportulae, collared but with no projections (white arrowheads). 28. Side view of marginal area showing striation, papillae, external openings of marginal fultoportulae ( $\mathrm{mfp}$ - two white arrows), and the cingulum consisting of an open valvocopula and several copulae (white arrow). 29. Detail of the central area with large areolae; external areolae are bigger and occluded by volae in places where ribs are fusing. 30. Broken valve view showing the different striation between the margins and the center, the steep transversal undulation and the valve thickness. 31. Marginal area with the external openings of marginal fultoportulae (white arrowheads), papillae, and the cingulum. 32. Broken valve view showing the simple structure of anastomosing ribs covered by a finely perforated silica layer. Scale bars: $25=5 \mu \mathrm{m} ; 26,28-32=2 \mu \mathrm{m} ; 27=1 \mu \mathrm{m}$ (27). 
PAILLÈS C. et al., New fossil genus and new extant species of Stephanodiscaceae (Guatemala)

length, some extending deep in the central zone to a central bright punctum. Marginal and central areas not distinctively structured. In small specimens, strong transversal undulation is attenuated and radiating striae are converging to a central ring.

Scanning electron microscopy (Figs 25-40)

Valves strongly undulated externally (Figs 25-26). Cingulum present, consisting of an open valvocopula and several copulae (Figs 27-28). Valve surface is irregular with sprinkled granules and prominent embossed ribs. The marginal striated area is circumferentially undulated with numerous granules; the mantle is gently sloping (Fig. 27). Striae consisting of 3-4 rows of finely aligned areolae alternating with reduced hyaline interstriae bearing near the valve margin big rounded openings corresponding to the external openings of marginal fultoportulae (Figs 27-28). The central area displays a steep tangential undulation (Fig. 29). If the junction between the valve face and the mantle is steeply marked vertically both on the elevated and depressed sides (Fig. 30), horizontally, from the elevated to depressed parts, the incline is smooth and gradual. On the internal side of the marginal area, striae become single rows of large rounded to oblong areolae that progressively become smaller and arranged to some extent into a stellate pattern (Fig. 31). Where ribs are fusing, external areolae are bigger and occluded by volae. Broken specimen displays a simple valve structure: a basal siliceous layer composed of anastomosing ribs starting from a central hollow and continuing to the valve rim where intercostal spaces are covered by a finely perforated silica layer (Fig. 32).

Internally, there is no central lamina inside the valve (Fig. 33). Costae are strongly silicified and elevated, extending from the valve rim to the valve center and fusing into a thick silicified hollow (Figs 34-35). The alveolar structure could be classified as complex as the alveolus bears in its middle a recessed/sunken costa that carries the marginal fultoportula (mfp) (Fig. 36). As such, mfp are located on every second striae and are composed of one tube and three satellite pores (Figs 37-38). The ring of $\mathrm{mfp}$ and $\mathrm{rm}$ stands just beneath marginal lamina. One single rimoportula $(\mathrm{rm})$ positioned on a recessed costa consisting of a short tube with a tangential slit that is always diametrally opposed to the raised side (Fig. 39). One single valve face fultoportula (vffp) - composed of one tube and three satellite pores - is always diametrically opposed to the rimoportula (Fig. 39). It appears eccentric since positioned on the raised part (Fig. 40). The external opening of the vffp is difficult to observe as it is positioned on the external slope of the raised central part (see in Fig. 26).

\section{Time range}

23-28 ka, abruptly absent after, considered extinct.

\section{Remarks}

Cyclocostis rolfii gen et sp. nov. belongs unequivocally to the family Stephanodiscaceae (Glezer \& Makarova 1986). In LM, it resembles Discostella woltereckii (Hust.) Houk \& Klee in Klee \& Houk (1996). However, SEM observations reveal a completely different structure in C. rolfii gen et sp. nov., particularly in the position of $\mathrm{mfp}$ and $\mathrm{rm}$ on costae, ruling out its belonging to the genus Discostella. With alternating and unequal striation pattern on the valve face, $C$. rolfii gen et sp. nov. also resembles Cyclotella stoermeri Khursevich \& Kociolek in Kociolek \& Khursevich (2013) in LM. Even though they share the absence of a central area, unequal striation, reduced alveoli and position of mfp and $\mathrm{rm}$ on recessed costae, $C$. rolfii gen et sp. nov. differs by the absence of centripetal roofing (central lamina) and thus the alveoli have no distinct border at the valve center side. The unequal striation visible in LM in C. rolfii gen et sp. nov. only corresponds to the way ribs are arranged internally: elevated, strongly silicified, anastomosing and joining in a central hollow. These thick radial ribs are the external characteristic features of the genus Stephanocostis Genkal \& Kuzmina represented by S. chantaica Genkal \& Kuzmina. However, these structures are internal in C. rolfii gen et sp. nov., whereas they are 
external in $S$. chantaica whose internal structure is flat with fine areolae forming \pm radial rows of starlike criba.

The strongly tangentially undulated valve is a character shared by Cyclotella and Pliocaenicus Round \& Håk., the latter genera being included into Lindavia by Nakov et al. (2015). The position and structure of mfp are also a common character. But unlike in some Cyclotella or Pliocaenicus, no domed criba are observed internally in Cyclocostis gen. nov. As the position of the rm within the ring of $\mathrm{mfp}$ in C. rolfii gen et sp. nov. differs from Pliocaenicus, it rules out its belonging to this genus.

The alveoli of $C$. rolfii gen et sp. nov. could be classified as complex, because there is a median fultoportula born on a recessed costa. However, structurally they are simple since not partially occluded by central lamina and widely open towards the valve center. The structure of alveoli of $C$. rolfii gen et sp. nov. rather corresponds to some extent to the marginal chambers defined by Lange \& Syvertsen (1989) as "a marginal space characterized by an opening on the inside of the valve encompassing two or more alveolus openings that is limited by coarse interstriae". These marginal chambers are present in Cyclostephanos novaezeelandiae (Cleve) Round in Theriot et al. (1987) or C. dubius (Hust.) Round in Theriot et al. (1987). However, the genus Cyclostephanos Round is largely heterogenous in terms of frustule morphology as it includes species with and without alveolar chambers. Except the marginal chambers, $C$. rolfii gen et sp. nov. shares no other characters with the genus Cyclostephanos.

The characteristics of the striae, composed of fine pori on the mantle and becoming uniseriate with large radially arranged areolae towards the center of the valve, as observed in C. rolfii gen et sp. nov., are shared with Paleotertiarius. Even though $C$. rolfii gen et sp. nov. and Paleotertiarius share characters such as strong ribs and the structure and position of $\mathrm{mfp}$, in Paleotertiarius, flat or concentrically undulated valves, internal domed criba and rimoportula located on the side of a costa inside the alveolus are morphological differences that exclude $C$. rolfii gen et sp. nov. from belonging to Paleotertiarius.

Figs 33-40 (next page). Type material of fossil lacustrine diatom Cyclocostis rolfii Paillès gen. et sp. nov.; SEM internal valve views. 33. Broken valve revealing internal structure; note the reduced cell cavity (white arrowhead). 34. Valve interior showing strong anastomosing ribs merging to a central siliceous ring; central lamina absent; marginal fultoportulae located on every $2^{\text {nd }}$ recessed costa; note the slightly deflected rimoportula (white arrow). 35. Valve interior of a small specimen with strong thick ribs and reduced alveoli, central lamina absent; note the single valve face fultoportula (white arrowhead) located near the valve margin on the raised central area; open valvocopula in place. 36. Broken valve margin showing complex alveolar structure: two thick ribs with a median recessed costa, more inwardly bent, carrying marginal fultoportula composed of one tube and three satellite pores. 37 . Valve interior of a small specimen with valvocopula. 38. Heart shaped alveoli due to the marginal fultoportula located on median recessed costa. 39. Internal valve view with marginal fultoportulae and rimoportula arranged in a ring below the valve margin; the single valve face fultoportula (double white arrowhead) is always on the opposite side from the rimoportula (single white arrowhead). 40. Detail of the single valve face fultoportula composed of a short tube and three satellite pores always in an eccentric position. Scale bars: $33,34=5 \mu \mathrm{m} ; 35,39=2 \mu \mathrm{m} ; 36-38=1 \mu \mathrm{m} ; 40=0.5 \mu \mathrm{m}$. 
PAILLÈS C. et al., New fossil genus and new extant species of Stephanodiscaceae (Guatemala)

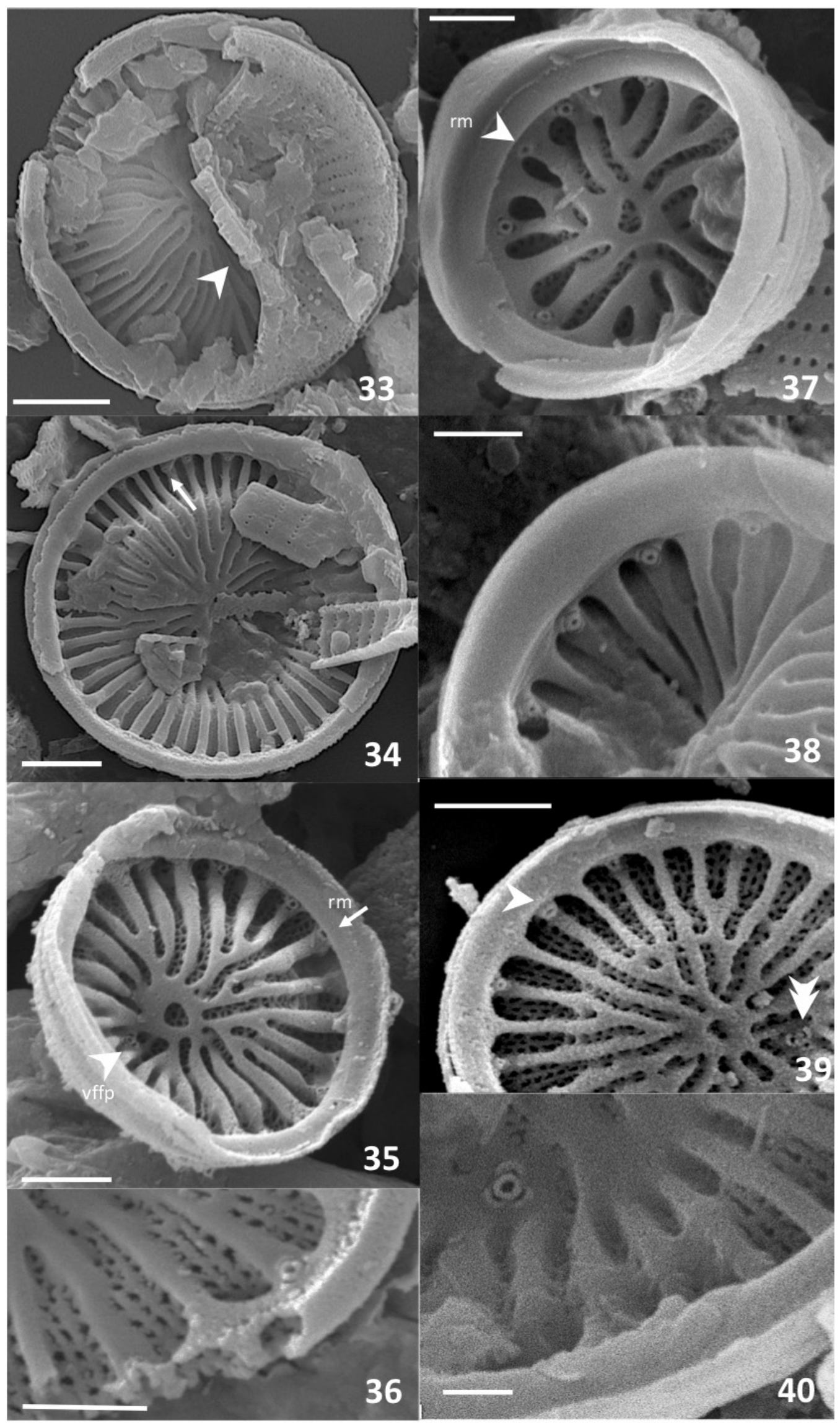


Genus Discostella Houk \& Klee

Discostella gabinii Paillès \& Sylvestre sp. nov.

Figs 41-58

\section{Etymology}

This taxon is named in honor of deceased Gabin Sylvestre, the courageous 7 years old nephew of F. Sylvestre.

\section{Type material}

\section{Holotype}

Slide PC0608732 and sediment PC0608730 deposited at the Laboratoire de Cryptogamie, Muséum national d'histoire naturelle (MNHN) Paris, France. Specimen on slide PC0608732 (Fig. 45) represents the holotype designated here.

\section{Isotype}

Slide ZU 11/31 and sediment R1285 deposited at the Friedrich Hustedt Diatom Center in Bremerhaven, Germany.

\section{Other material examined}

Modern specimens collected from Cenote Juarez and Lake Amatitlan (see Table 1).

\section{Type locality}

GUATEMALA • Department of Petén, Lake Petén-Itzá; $16^{\circ} 15^{\prime} 50^{\prime \prime} \mathrm{N}, 89^{\circ} 15^{\prime} 00^{\prime \prime} \mathrm{W}$; lacustrine sediment in core PI-06; sample GLAD9-PET06-6B-18E1- 35.4-36.4 cm (51.53 m below lake floor) consisting of dark gray clayish sediment; core collected in February 2006.

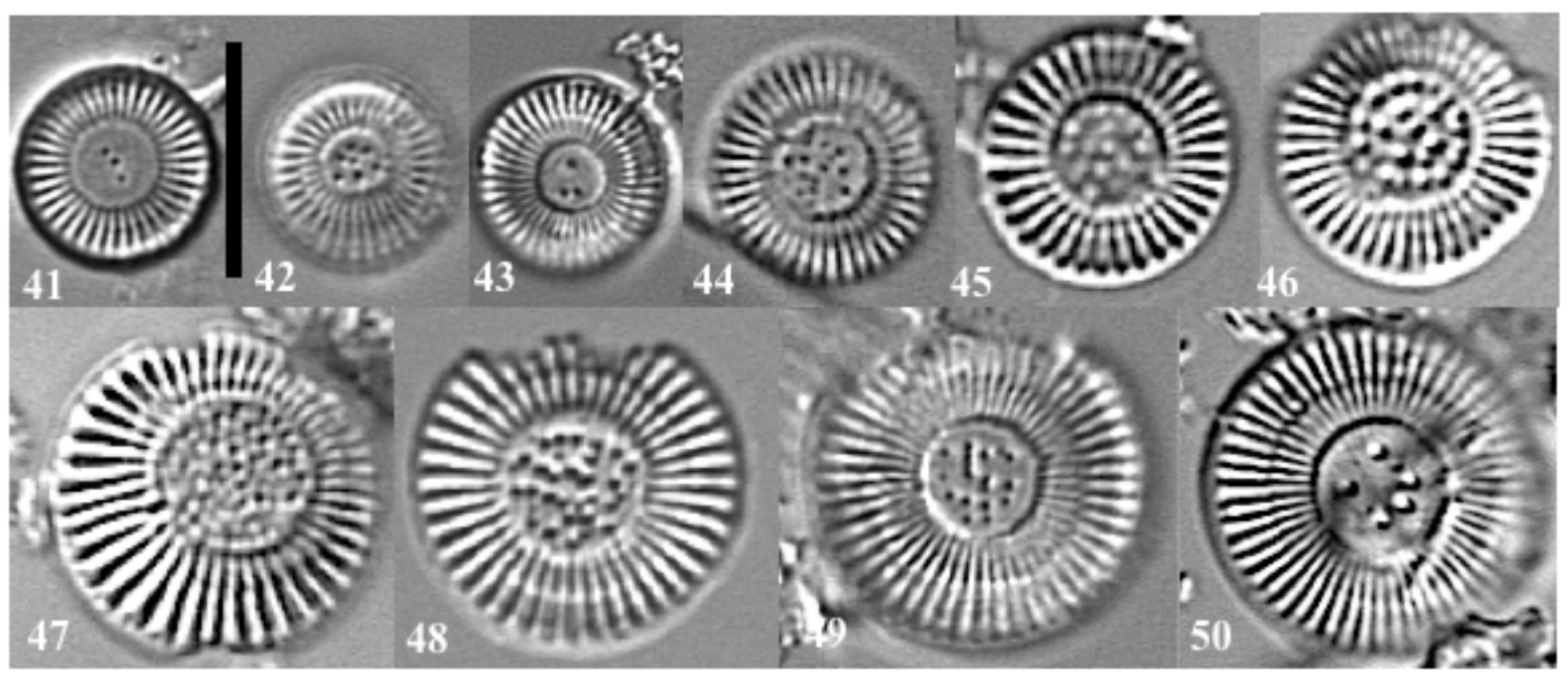

Figs 41-50. Discostella gabinii Paillès \& Sylvestre sp. nov., Lake Petén-Itzá (Guatemala); LM valve views. 41-42. Modern specimens of $D$. gabinii sp. nov. from Cenote Juarez. 43-44. Modern specimens of D. gabinii sp. nov. from Lake Amatitlan. 45-50. Type material of fossil lacustrine diatom D. gabinii sp. nov. 45. Holotype (MNHN, slide PC060873). 48-50. A shadow line is visible in large specimens. Scale bar $=10 \mu \mathrm{m}$. 


\section{Description}

Light microscopy (Figs 41-50)

Cells quadrangular in connective view. Valvar views circular and flat, $8-18 \mu \mathrm{m}$ in diameter with a small central area ( $1 / 3$ of the valve radius). Central area with 5 to $>30$ scattered large areolae, the number being independent of valve size (Figs 41-50). When numerous, the scattered areolae give the impression of a colliculate/granular flat center. The marginal area of the valve face has radial striae numbering from 10 to 14 in $10 \mu \mathrm{m}$. The striae are long ( $2 / 3$ of the valve radius) and of equal length. On large specimens, marginal striation is crossed circumferentially by a ring ('Schattenlinie' = 'shadow line') close to the valve center (Figs 48-50).

\section{Scanning electron microscopy (Figs 51-58)}

Valves flat to barely concave externally with gently sloping mantle. Central area covered with several scattered punctae separated by knots (colliculate) bearing papillae (Figs 51-52). Radiating striae starting on the mantle as crescents of three to five rows of fine areolae $(60-70$ areolae $/ 10 \mu \mathrm{m})$, merging into two rows near the central area and ending with a single large pore (Figs 53-54). The central area is thus bordered by a ring of large areolae. On the valve face, striae are depressed, whereas they are smooth on the mantle. Near the valve margin, every third to fifth striae, pores just below the crescent of fine areolae mark the external openings of marginal fultoportulae (Fig. 54). Interstriae are narrow, domed and granular on the valve face, whereas smooth on the mantle. The mantle is unornamented except for the large round openings of marginal fultoportulae and few papillae. The external opening of the rimoportula was not observed, although it should be positioned at the same level since it is within the ring of marginal fultoportulae.

Interior views of the valve show a flat to slightly concave but smooth central area with none or single areola (Figs 55-56). The internal lamina spread from the valve center to $2 / 3$ of the valve radius. The alveoli are thus medium sized, oblong and of unequal length, those bearing marginal fultoportulae being longer (Fig. 56). Marginal fultoportulae with two laterally positioned satellite pores surrounding a short tubulus are located at the distal extremity of every third to fourth alveoli (Fig. 57). One nearly sessile rimoportula with vertically orientated lips located between two costae at the edge of an alveolus and within the ring of marginal fultoportulae (Fig. 58). Girdle bands present, an open valvocopula with two copulae (Fig. 56); a row of fine pores is noted on the interior of the girdle band (Fig. 58).

\section{Time range}

Present since at least $84 \mathrm{ka}$ in the geological record, present in Lake Amatitlan and Cenote Juarez $\left(20^{\circ} 48^{\prime} 09.6^{\prime \prime} \mathrm{N}, 87^{\circ} 27^{\prime} 23.8^{\prime \prime} \mathrm{W}\right)$ in March 2008.

\section{Remarks}

With marginal fultoportulae and rimoportula being located between costae on the marginal side of the alveolus, Discostella gabinii sp. nov. belongs undoubtedly to the genus Discostella. Amongst the 15 species of Discostella described so far (Kociolek et al. 2018), D. gabinii sp. nov. showed some resemblance to D. areolata (Hust.) Houk \& Klee. However, in LM they look somewhat different, the unique holotype of $D$. areolata having coarser striation (6-9 striae in $10 \mu \mathrm{m})$ and a large colliculate central area (Houk et al. 2010: table 330, figs 1-7). A reexamination of the original material of $D$. areolata from Hustedt by Tagliaventi \& Cavinaci (2002) provided unambiguous SEM images of external views but only ambiguous internal views since $D$. areolata was rare and mixed with $D$. stelligera (Cleve \& Grunow) Houk \& Klee var. robusta (Hust.) Houk \& Klee in the original material. The central area of $D$. areolata is concave or convex, smooth or consisting of alternating impressions and protrusions of various size with small punctae being mainly located in the depressions. Sometimes domed radiating striae resembling a poorly defined rosette are present in the central area. In D. gabinii sp. nov., the central 
area is always flat, indeed colliculate but with large punctae inserted in the depressions. Moreover, in D. areolata, striae are depressed and costae elevated on their entire length, whereas in D. gabinii sp. nov., this feature is restricted to the valve face, the mantle being smooth. Internally, two types of central area could be attributed to $D$. areolata: smooth with no central fultoportula or smooth with a punctum. These variations are also visible in $D$. gabinii sp. nov. Despite uncertainties related to the species described as D. areolata, D. stelligera var. robusta and D. stelligera var. hyalina (Hust.) Houk \& Klee, the structure of marginal costae and the position of marginal fultoportulae and rimoportula are quite different compared to that of D. gabinii sp. nov. Marginal costae can be forked or not. Furthermore, marginal fultoportulae (composed of one tube and two satellite pores placed horizontally) and rimoportula (vertically orientated slit) are inserted within the alveolar chamber.

Another somewhat similar species is D. elentarii (Alfinito \& Tagliaventi) Houk \& Klee with flat valves, although it has a large central area with radiate rows of granules and scattered punctae, coarsely striated (9-10 striae in $10 \mu \mathrm{m})$ and reduced marginal area, and a marginal row of small spinae. Internally, it has similar smooth central area (sometimes with a faint stellate pattern) and similar structure and position of $\mathrm{mfp}$ and $\mathrm{rm}$. The only difference is that, internally, in D. elantarii costae are broadening toward the valve margin with a punctum in the middle giving the impression of forked costae. After reexamination of D. elantarii by Knapp et al. (2006), it appears that the correct striae density is 8-14 and that each collared marginal fultoportula and the single rimoportula are surrounded by satellite pores covered by a cribum. Although we did not use a field emission variable pressure SEM, such structures are absent in $D$. gabinii sp. nov. Interestingly, it is the only morphological feature used to differentiate $D$. elantarii from D. stelligera in SEM (Knapp et al. 2006). The presence of pores in the girdle band is also a subtle character shared by $D$. elentarii and $D$. gabinii sp. nov. that requires further investigation. Despite morphological similarities with $D$. areolata and D. elentarii, D. gabinii sp. nov. possesses distinctive characteristics that are sufficient to define a new species. Stelligeroid species of Cyclotella have been transferred to the genus Discostella on the basis of the unique position of strutted and labiate processes (Houk et al. 2010). However, difficulties arise because these species are often heterovalvate and size and morphological variations exist. As reported by Tagliaventi \& Cavinaci (2002), Alfinito \& Tagliaventi (2002) and Knapp et al. (2006), only minute distinctive features allow one to differentiate $D$. areolata, $D$. stelligera, D. stelligera var. robusta, D. stelligera var hyalina and D. elantarii. This latter species is endemic to New Zealand and coexists with D. stelligera in two lakes. Knapp et al. (2006) suggest that considering the difficulty in differentiating them, they could be sibling species and $D$. elantarii may descend from $D$. stelligera.

Figs 51-58 (next page). Type material of fossil lacustrine diatom Discostella gabinii Paillès \& Sylvestre sp. nov., Lake Petén-Itzá (Guatemala); SEM valve views. 51. External valve view showing a colliculate central area with scattered areolae, knots and papillae, and a marginal area with finely punctuated radiating striae. 52. External view of a large specimen with numerous areolae in the central area; the striae have rounded ends near the margin. 53. Valve view of a complete corroded frustule showing valve interior with medium sized alveoli and marginal fultoportulae located in the middle of every $3^{\text {rd }}$ to $5^{\text {th }}$ alveoli; open valvocopula present. 54. External openings of marginal fultoportulae located just below the crescent end of the striae (white arrowheads). 55. Internal valve view with medium sized alveoli and a large expansion of the smooth central lamina; marginal fultoportulae located on every $3^{\text {rd }}$ to $5^{\text {th }}$ alveoli. 56. Internal valve view with smooth central area with a single areola; open valvocopula present. 57. Detail view of valve margin; marginal fultoportulae composed of one tube with two satellite pores positioned on the external ends of the alveoli; rimoportula with vertically orientated lips, located between two costae at the edge of an alveolus and within the ring of marginal fultoportulae. 58. Detail view of the valve margin with an eroded marginal fultoportula at the edge of the alveolus; note a row of fine pores on the interior of the girdle band (white arrowheads). Scale bars $=51-56=2 \mu \mathrm{m} ; 57-58=$ $1 \mu \mathrm{m}$. 
PAILLÈS C. et al., New fossil genus and new extant species of Stephanodiscaceae (Guatemala)

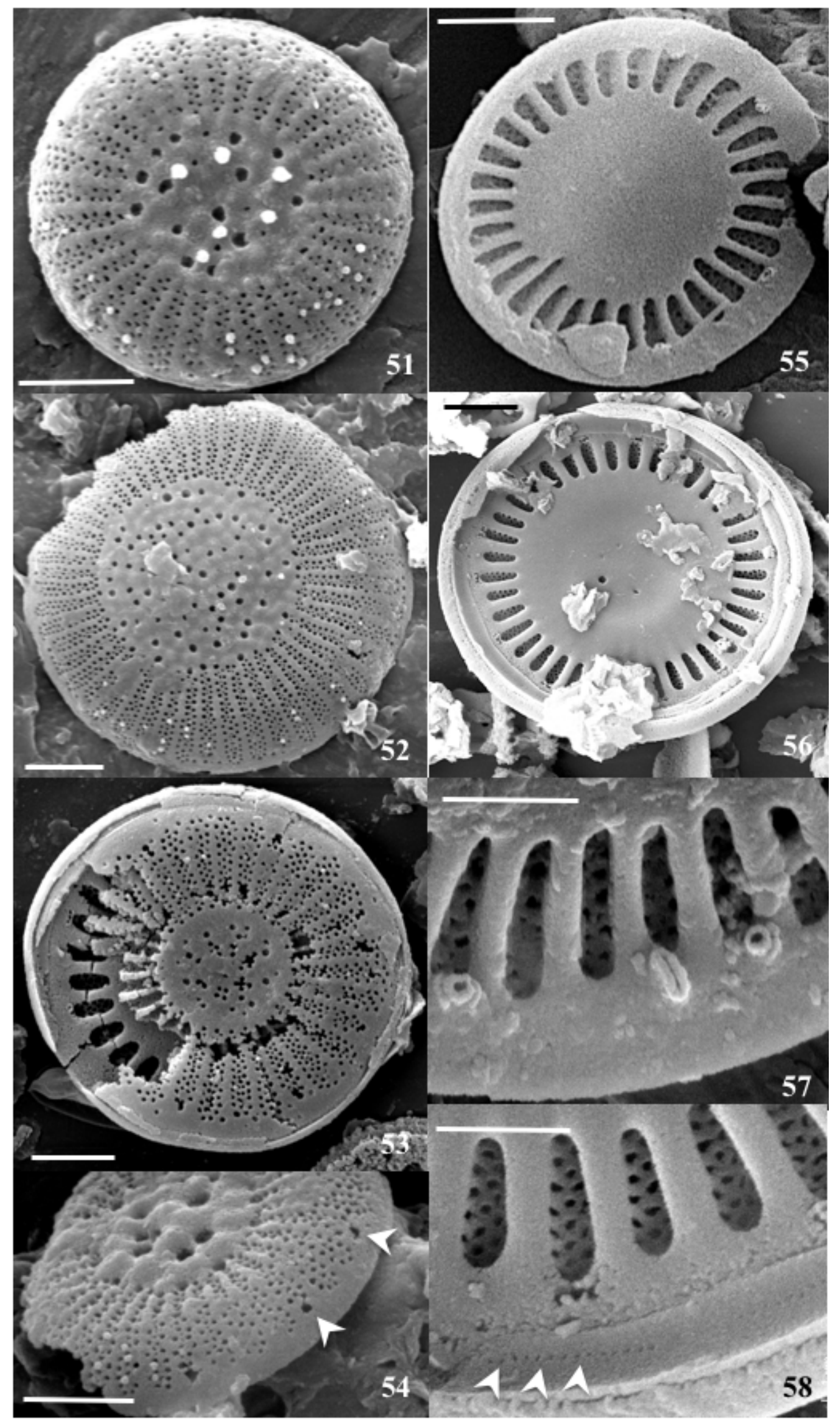




\section{Stratigraphic diatom succession}

The base of the section ( $84 \mathrm{ka}$ ) is characterized by an assemblage dominated (58-90\%) by Aulacoseira granulata (Ehrenb.) Simonsen and A. ambigua (Grunow) Simonsen (Fig. 59). Cyclotella meneghiniana and Discostella stelligera occurred punctually $(<20 \%)$ between 82.3 and $80 \mathrm{ka}$. The Aulacoseira dominated assemblage persists up to $70 \mathrm{ka}$ then greatly recedes $(<20 \%)$ up to $1.5 \mathrm{ka}$. From around $60 \mathrm{ka}$, we observed successive occurrences of D. stelligera, C. meneghiniana, Discostella gabinii sp. nov. and Cyclotella caspia Grunow. At $45 \mathrm{ka}$, Cyclotella petenensis takes over the assemblage (73-97\%) then declines abruptly at $31.5 \mathrm{ka}$. Prior to the collapse of C. petenensis, Discostella gabinii sp. nov. returned with fluctuating percentages for about $5 \mathrm{ka}$. Then, Cyclocostis rolfii gen et sp. nov. emerges at $26.9 \mathrm{ka}$, develops with fluctuating abundances with Nitzschia amphibioides Hust., Mastogloia smithii Thwaites, M. elliptica (C.Agardh) Cleve and Navicula seminuloides Hust. At $22.2 \mathrm{ka}$, Cyclocostis rolfii gen et sp. nov. disappears definitely while Cyclotella petenensis reoccurs. At first, $C$. petenensis coexists with Discostella gabinii sp. nov. (10-60\%) then it takes over when D. gabinii sp. nov. declines. The dominant C. petenensis persists until $16.1 \mathrm{ka}$ and does not reoccur thereafter in the sequence.

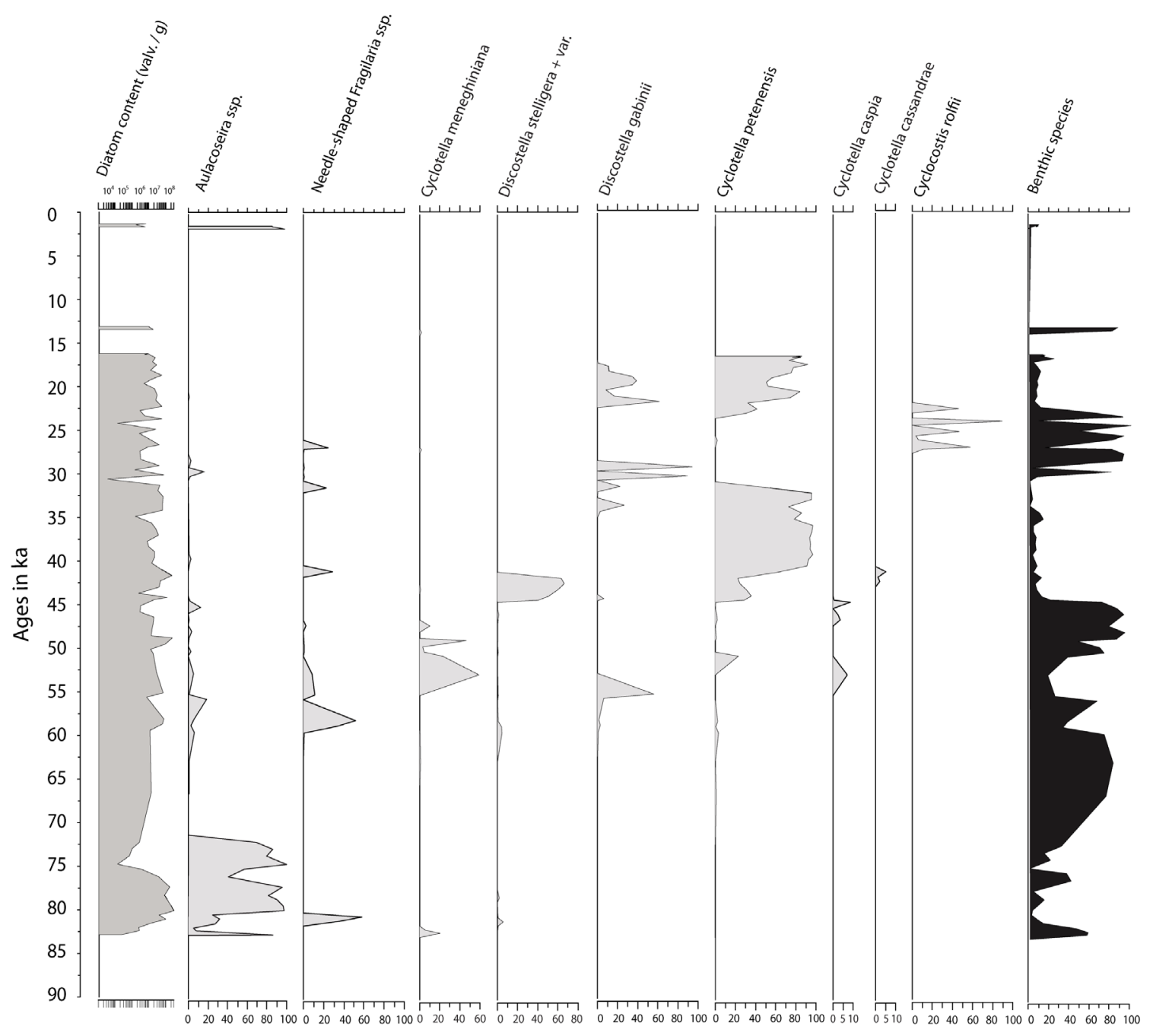

Fig. 59. Diagram showing the succession of Stephanodiscaceae Glezer \& Makarova in Pleistocene sediments (0-84 ka) from Lake Petén-Itzá (Guatemala). 
PAILLÈS C. et al., New fossil genus and new extant species of Stephanodiscaceae (Guatemala)

\section{Ecology and associated diatom flora}

In the modern dataset (Pérez et al. 2013), Discostella gabinii sp. nov. was initially identified as "Cyclotella sp22" (code CP22) and another species was identified as "Discostella aff. pseudostelligera" (CYAP). When analyzing the fossil flora and diagnosing $D$. gabinii sp. nov., we re-examined modern samples and observed that the two species were similar. "Discostella aff. pseudostelligera" and "Cyclotella sp22" were therefore combined together under the name Discostella gabinii sp. nov.

Conductivity, which is related to the precipitation gradient and marine influence on the Yucatan Peninsula, is the main variable that structures diatom, ostracod and cladoceran communities (Pérez et al. 2013). Discostella gabinii sp. nov. occurs in 11 water bodies of the Yucatan Peninsula (Table 1). In the Guatemalan highlands, its maximum occurrence (13\%) was in Lake Amatitlan, a hypereutrophic alkaline lake spreading over $15.2 \mathrm{~km}^{2}$ at $1200 \mathrm{~m}$ a.s.l. altitude. Water was calcium-bicarbonate rich, warm $\left(22.6^{\circ} \mathrm{C}\right)$, with electrical conductivity of $630 \mu \mathrm{S} / \mathrm{cm}$ and high dissolved oxygen content (17.8 mg/L). Subdominant species were Aulacoseira granulata, Cyclotella meneghiniana and Nitzschia pseudofonticola Hust. In Cenotes Juarez, D. gabinii sp. nov. reached 4.8\% in an assemblage dominated by Achnanthidium exiguum (Grunow) Czarn. and A. lineare W.Sm. Water was warm $\left(27.9^{\circ} \mathrm{C}\right)$ and alkaline with relatively high dissolved oxygen content $(8.7 \mathrm{mg} / \mathrm{L})$. Conductivity was $643 \mu \mathrm{S} / \mathrm{cm}$. Water analyses determined $\mathrm{Ca}^{2+}(68.3 \mathrm{mg} / \mathrm{L})$ and $\mathrm{Mg}^{2+}(23 \mathrm{mg} / \mathrm{L})$ as the dominant cations and $\mathrm{HCO}_{3}^{-}$ (292.7 mg/L) as important anion. Overall, D. gabinii sp. nov. seems to tolerate varying conductivities but is most abundant in alkaline, low conductivities $(600-650 \mu \mathrm{S} / \mathrm{cm})$ and calcium-bicarbonated waters.

Cyclotella petenensis, although considered to be fossil at the time of description (Paillès et al. 2018), was identified as C. meneghiniana (CYMG) in the modern dataset mainly due to the fact that specimens were small in size, tangentially undulated with $<5$ valve face fultoportulae on the raised part. Once diagnosed as a new species in the sedimentary record, a re-examination of modern samples revealed that C. petenensis was present in low percentages $(<4 \%)$ in five water bodies. Only in Lake Yalahau (Yucatan lowlands), C. petenensis reached 17.8\% (Table 1). Of all water bodies investigated, Lake Yalahau had the highest diatom species richness. In this lake, water is shallow, warm $\left(28.8^{\circ} \mathrm{C}\right)$ and alkaline $(\mathrm{pH} 8.9)$ with a high dissolved oxygen content $(8.7 \mathrm{mg} / \mathrm{L})$. Electrical conductivity is high 2350 $\mu \mathrm{S} / \mathrm{cm}$. Water was magnesium $(136.8 \mathrm{mg} / \mathrm{L})$ and bicarbonate $(707.4 \mathrm{mg} / \mathrm{L})$ rich. Its diatom population was composed of $33 \%$ of $C$. meneghiniana accompanied by Brachysira australofollis Lange-Bert. \& Gerd Moser, B. neoexilis Lange-Bert., Encyonema densistriata Novelo, Tavera \& Ibarra and Fragilaria famelica (Kütz.) Lange-Bert. In coastal Lake Progreso where $C$. petenensis represents $4 \%$ of the flora, water conductivity was $2040 \mu \mathrm{S} / \mathrm{cm}$. In the modern samples, it appears that $C$. petenensis seems to favor waters with conductivities close to $2000 \mu \mathrm{S} / \mathrm{cm}$.

\section{Discussion}

In terms of morphology, Stephanodiscaceae encompass a wide range of valve structures and thus genera. Interestingly, Cyclocostis gen. nov. possess distinctive morphological characters that can be found in species of genera Cyclostephanos, Cyclotella (Lindavia, Discostella, Pantocsekiella), Stephanocostis, Pliocaenicus, and Paleotertiarius. Conversely, the combination of these peculiar morphological features, which differentiate it from these genera, can be used to justify the definition of a new genus. In terms of valve structure, when looking at internal valve views of species of Stephanodiscus Ehrenb., Stephanocostis and most species of Cyclostephanos, the striking features are 1) the absence of alveoli and thus ribs, these being rather hyaline interfascicles and 2) the presence of domed criba covering internal areolae. Nevertheless, internal domed criba are always present in Paleotertiarius and Pliocaenicus and in some species of Lindavia. But Paleotertiarius and Pliocaenicus as well as some species of Cyclostephanos (C. novaezeelandiae and C. dubius) are also characterized by ghost or reduced alveoli. In contrast, internal alveolate structure - simple or complex - is a widespread structural component of 
Table 1 (continued on the next page). Selected limnological and chemical data from lakes (single measurements in 2005 or 2008) containing Discostella gabinii Paillès \& Sylvestre sp. nov. and Cyclotella petenensis Sylvestre, Paillès \& Escobar in the Yucatan Peninsula after Pérez et al. (2013). n.d. = not determined.

\begin{tabular}{|c|c|c|c|c|c|c|c|}
\hline \multirow[b]{2}{*}{ Lake name } & \multicolumn{3}{|c|}{ Guatemalan highlands } & \multicolumn{4}{|c|}{ Peten lowlands } \\
\hline & Amatitlan & Atescatempa & Guija & Izabal & Salpeten & Bacalar-1 & Bacalar-2 \\
\hline Lake ID & 19 & 22 & 21 & 1 & 26 & 13 & 13 \\
\hline Latitude $\mathbf{N}$ & $14^{\circ} 26^{\prime} 03.7^{\prime \prime}$ & $14^{\circ} 13^{\prime} 01.1^{\prime \prime}$ & $14^{\circ} 15^{\prime} 43.7^{\prime \prime}$ & $15^{\circ} 29^{\prime} 24.5^{\prime \prime}$ & $16^{\circ} 58^{\prime} 38.2^{\prime \prime}$ & $18^{\circ} 39^{\prime} 54.0^{\prime \prime}$ & $18^{\circ} 39^{\prime} 54.0^{\prime \prime}$ \\
\hline Longitude W & $90^{\circ} 32^{\prime} 58.6^{\prime \prime}$ & $89^{\circ} 41^{\prime} 39.2^{\prime \prime}$ & $89^{\circ} 32^{\prime} 11.3^{\prime \prime}$ & $89^{\circ} 08^{\prime} 32.7^{\prime \prime}$ & $89^{\circ} 40^{\prime} 30.9^{\prime \prime}$ & $88^{\circ} 23^{\prime} 27.0^{\prime \prime}$ & $88^{\circ} 23^{\prime} 27.0^{\prime \prime}$ \\
\hline \multicolumn{8}{|l|}{ Species (\%) } \\
\hline C. petenensis & 0.0 & 0.0 & 0.0 & 0.8 & 0.0 & 0.7 & 2.1 \\
\hline D. gabinii sp. nov. & 13.2 & 0.3 & 5.0 & 0.0 & 2.0 & 0.2 & 0.2 \\
\hline \multicolumn{8}{|l|}{$\begin{array}{l}\text { Limnological } \\
\text { parameters }\end{array}$} \\
\hline $\begin{array}{l}\text { Max sampling } \\
\text { depth }(\mathrm{m})\end{array}$ & 0.5 & 0.5 & 0.5 & 14 & 38 & 65 & 16.3 \\
\hline Altitude (m a.s.1.) & 1200 & 587 & 433 & 4 & 114 & 1 & 1 \\
\hline Surface area $\left(\mathrm{km}^{2}\right)$ & 23 & 1.1 & 45 & 645 & 2.9 & 51 & 51 \\
\hline Temperature $\left({ }^{\circ} \mathrm{C}\right)$ & 22.8 & 27.3 & 26.2 & 26.4 & 25.4 & 28.8 & 27.1 \\
\hline $\mathrm{DO}_{2}(\mathrm{mg} / \mathrm{L})$ & 18.7 & 6.7 & 7.7 & 7.6 & 0.8 & 0.4 & 7.9 \\
\hline $\mathrm{pH}$ & 9.3 & 8.0 & 8.4 & 8.3 & 7.3 & 6.9 & 7.8 \\
\hline Cond. $(\mu \mathrm{S} / \mathrm{cm})$ & 630 & 283 & 206 & 216 & 4250 & 1400 & 1226 \\
\hline Secchi depth (m) & $0.1-0.8$ & 0.1 & 1.4 & n.d. & 0.8 & 10.3 & 10.3 \\
\hline \multicolumn{8}{|l|}{$\begin{array}{l}\text { Chemical variables } \\
(\mathrm{mg} / \mathrm{L})\end{array}$} \\
\hline $\mathrm{HCO}_{3}^{-}$ & 234.8 & 182.9 & 121.9 & 119.6 & 140.3 & 305.6 & 187.3 \\
\hline $\mathrm{SO}_{4}^{2-}$ & n.d. & n.d. & n.d. & 8.4 & n.d. & 1337.2 & 1300 \\
\hline $\mathrm{Cl}^{-}$ & n.d. & n.d. & n.d. & 6.6 & n.d. & 81.3 & 85 \\
\hline $\mathrm{Na}^{+}$ & 123.8 & 23.1 & 16.5 & 7.5 & 128.2 & 70.9 & 44.9 \\
\hline $\mathrm{K}^{+}$ & n.d. & n.d. & n.d. & 1.9 & n.d. & 0.7 & 0.7 \\
\hline $\mathrm{Ca}^{2+}$ & 23.2 & 23.3 & 26.9 & 25.9 & 795.8 & 460.3 & 399.6 \\
\hline \multirow[t]{2}{*}{$\mathrm{Mg}^{2+}$} & 16.5 & 10.5 & 8.07 & 7.3 & 360.7 & 80.6 & 77.6 \\
\hline & \multicolumn{4}{|c|}{ Yucatan lowlands } & Cenotes & Coastal & Ponds \\
\hline Lake name & Ocom & Coba & Yalahau-05 & Yalahau-08 & Juarez & Progreso & Belize 2 \\
\hline Lake ID & 15 & 61 & 18 & 18 & 60 & 35 & 7 \\
\hline Latitude N & $19^{\circ} 28^{\prime} 28.6^{\prime \prime}$ & $20^{\circ} 29^{\prime} 40.2^{\prime \prime}$ & $20^{\circ} 39^{\prime} 25.9^{\prime \prime}$ & $20^{\circ} 39^{\prime} 25.9^{\prime \prime}$ & $20^{\circ} 48^{\prime} 09.6^{\prime \prime}$ & $18^{\circ} 13^{\prime} 05.2^{\prime \prime}$ & $17^{\circ} 18^{\prime} 17.9^{\prime \prime}$ \\
\hline Longitude W & $88^{\circ} 03^{\prime} 17.9^{\prime \prime}$ & $87^{\circ} 44^{\prime} 19.2^{\prime \prime}$ & $89^{\circ} 13^{\prime} 02.0^{\prime \prime}$ & $89^{\circ} 13^{\prime} 02.0^{\prime \prime}$ & $87^{\circ} 20^{\prime} 23.8^{\prime \prime}$ & $88^{\circ} 24^{\prime} 35.2^{\prime \prime}$ & $88^{\circ} 29^{\prime} 18.9^{\prime \prime}$ \\
\hline \multicolumn{8}{|l|}{ Species (\%) } \\
\hline C. petenensis & 0.0 & 0.0 & 1.3 & 17.8 & 0.0 & 4.0 & 0.0 \\
\hline D. gabinii sp. nov. & 3.7 & 0.6 & 1.3 & 0.0 & 4.8 & 0.0 & 0.1 \\
\hline
\end{tabular}


PAILLÈS C. et al., New fossil genus and new extant species of Stephanodiscaceae (Guatemala)

Table 1 (continued). Selected limnological and chemical data from lakes (single measurements in 2005 or 2008) containing Discostella gabinii Paillès \& Sylvestre sp. nov. and Cyclotella petenensis Sylvestre, Paillès \& Escobar in the Yucatan Peninsula after Pérez et al. (2013).

\begin{tabular}{|c|c|c|c|c|c|c|c|}
\hline \multirow[b]{2}{*}{ Lake name } & \multicolumn{4}{|c|}{ Yucatan lowlands } & \multirow{2}{*}{$\begin{array}{c}\text { Cenotes } \\
\text { Juarez }\end{array}$} & \multirow{2}{*}{$\begin{array}{l}\text { Coastal } \\
\text { Progreso }\end{array}$} & \multirow{2}{*}{$\begin{array}{l}\text { Ponds } \\
\text { Belize } 2\end{array}$} \\
\hline & Ocom & Coba & Yalahau-05 & Yalahau-08 & & & \\
\hline \multicolumn{8}{|l|}{$\begin{array}{l}\text { Limnological } \\
\text { parameters }\end{array}$} \\
\hline $\begin{array}{l}\text { Max sampling } \\
\text { depth }(\mathrm{m})\end{array}$ & 10 & 0.5 & 11.5 & 11.5 & 0.5 & 3.15 & 0.5 \\
\hline Altitude (m a.s.l.) & 1 & 7 & 2 & 2 & 14 & 5 & 33 \\
\hline Surface area $\left(\mathrm{km}^{2}\right)$ & 0.25 & 0.35 & 0.25 & 0.25 & 0.03 & 7.2 & \\
\hline Temp. $\left({ }^{\circ} \mathrm{C}\right)$ & 25 & 28.9 & 25 & 28.8 & 27.9 & 26.4 & 27.4 \\
\hline $\mathrm{DO}_{2}(\mathrm{mg} / \mathrm{L})$ & 0.8 & 8.7 & 0.7 & 8.7 & 8.7 & 7 & 7.5 \\
\hline $\mathrm{pH}$ & 7.4 & 8.5 & 8.6 & 8.9 & 8.1 & 8.2 & 8.0 \\
\hline Cond. $(\mu \mathrm{S} / \mathrm{cm})$ & 777 & 1213 & 1138 & 2350 & 643 & 2040 & 244 \\
\hline Secchi depth (m) & 5.5 & 0.9 & n.d. & 1.1 & 1.6 & 1.3 & n.d. \\
\hline \multicolumn{8}{|l|}{$\begin{array}{l}\text { Chemical variables } \\
(\mathrm{mg} / \mathrm{L})\end{array}$} \\
\hline $\mathrm{HCO}_{3}^{-}$ & 130.6 & 256.1 & 607.2 & 707.4 & 292.7 & 213.4 & 180.1 \\
\hline $\mathrm{SO}_{4}^{2-}$ & 685.9 & n.d. & 337.1 & n.d. & n.d. & n.d. & 6.4 \\
\hline $\mathrm{Cl}^{-}$ & 114.7 & n.d. & 145.4 & n.d. & n.d. & n.d. & 2.6 \\
\hline $\mathrm{Na}^{+}$ & 125.2 & 126.5 & 224 & 336.5 & 53.3 & 483.6 & 3.66 \\
\hline $\mathrm{K}^{+}$ & 3.5 & n.d. & 16.9 & n.d. & n.d. & n.d. & 1.6 \\
\hline $\mathrm{Ca}^{2+}$ & 155.2 & 99.7 & 18.8 & 89.6 & 68.3 & 189.4 & 45.0 \\
\hline $\mathrm{Mg}^{2+}$ & 44.6 & 5.4 & 101.4 & 136.8 & 23.0 & 59.6 & 2.28 \\
\hline
\end{tabular}

Cyclotella s. str., Lindavia, Pantocsekiella and Discostella. As in Paleotertiarius and Pliocaenicus, the alveolus (Anonymous 1975; Houk et al. 2010) is a chamber opening to the inside of the cell by small or large opening with a perforate outer layer. Thus, the degree of occlusion of the alveolus is determined by centrifugal roofing. Consequently, contact between the cell and the exterior is highly reduced by the presence of internal central lamina (Servant-Vildary 1986). Similarly, in more simply structured valves of Stephanodiscus, Cyclostephanos and Stephanocostis, the presence of domed criba is assumed to reduce contact between the cell and the exterior.

In morphogenesis of centric diatoms, valves are systems of silica ribs, which grow out from a circular center during valve formation (Round et al. 1990). They are formed within silica deposition vesicle (SDV) enclosed in the silicalemma, starting with a small, thin disc composed of radial bunched siliceous strands from the center (Kaluzhnaya 2006). According to Bedoshvili \& Likhoshway (2019), valve morphogenesis in centric diatoms begins with a formation of a ring (annulus) from which the ribs radiate centrifugally as the SDV grows and until the mantle is formed (=horizontal growth). Vertical growth occurs by silica deposition to thicken the valve and to differentiate fine structures such as areolae and various processes. Structurally, Cyclocostis gen. nov. appears simple: a web of radiating ribs starting from a central silicified ring covered by a coarsely perforated silica layer. The central ring represents a remainder of the annulus that was never filled in. Additionally, striae are reduced to two ribs covered with a perforated layer, and alveoli are widely open to the valve center. The frustule is strongly deformed and, consequently, has a larger surface area compared to a flat disc. Futhermore, the cell 
cavity is reduced (see the thickness of the frustule in Fig. 33). It could be anticipated that such simple construction combined with a large surface area would greatly expose the cell to surrounding waters as well as facilitate communication with the outside environment.

The species of diatoms are discerned by phenotypic characters. According to Benton \& Pearson (2001), the process of speciation is too slow to be observed directly. However, along an upper Miocene lacustrine sequence, populations of triangular Cyclotella sp. exhibit complexification of their alveoli suggesting a trend toward a reduced contact between the cell and its surrounding environment (Servant-Vildary 1986). Similarly, Theriot et al. (2006) observed a morphological shift in the Stephanodiscus niagarae C.Ehrenb./S. yellowstonensis E.C.Ther. \& Stoermer complex between 13.7 and $10.0 \mathrm{ka}$. They suggest that directional morphological evolution strongly associated with continuous environmental change would account for the evolution of $S$. yellowstonensis. Additionally, in Pleistocene sedimentary sequences from lakes Ohrid and Prespa, morphological variations (valve diameter, striae morphology, number of ribs and valve face fultoportulae) in Cyclotella populations suggested the expression of environmental factors (Cvetkoska et al. 2014). Interestingly, these studies only concern centric diatoms, the only study on pennate diatoms in lacustrine sequences concluded that levels of morphological differentiation were likely a consequence of limited dispersal (Evans et al. 2009).

In the PI-6 sedimentary record, from around 60 to $16.1 \mathrm{ka}$, we observe a succession of Cyclotella meneghiniana, Discostella stelligera, D. gabinii sp. nov., C. petenensis and Cyclocostis rolfii gen et sp. nov. that could evoke fluctuations of the lacustrine environment. A similar interpretation was made by Bradbury (1971) in a $>46$ ka diatom record from Lake Texcoco in Mexico where Cyclotella cf. stylorum (probably C. petenensis), C. quillensis L.W.Bailey and C. striata (Kütz.) Grunow alternated and reflected changes in salinity. He noticed that their distribution throughout the core was an alternation of ecotypes. From a morphological point of view, C. petenensis and C. cassandrae are probably variations of C. meneghiniana, initially present in our record (Paillès et al. 2018). Similarly, Discostella gabinii sp. nov. could also be a variation of $D$. stelligera firstly present in the record. For the newly described Cyclocostis gen. nov., its basic structure and the strong deformation of the valve suggest enhanced communication between the cell and the exterior. During $5 \mathrm{ka}$, Cyclocostis gen. nov. alternates with benthic species such as Nitzschia amphibioides, Mastogloia smithii, M. elliptica and Navicula seminuloides. As such, its punctual presence could also be the expression of local and rapid changes in the environment.

Overall, the succession of the species of Cyclotella, Discostella and Cyclocostis gen. nov. in our record could represent eco-phenotypic responses to environmental change/stress. Changes in water conductivity and/or water level fluctuations could be evoked as suggested by the presence of benthic mesosaline to hypersaline species developing between Cyclotella, Discostella and Cyclocostis gen. nov. episodes. Except for Cyclotella cassandrae and Cyclocostis rolfii gen et sp. nov. that were not identified in the modern dataset, all other centric species are still extant. Thus, a calibration of the modern data set in order to perform $\mathrm{pH}$ and conductivity transfer functions in the fossil record will be considered in future studies.

\section{Acknowledgements}

Drilling of Lake Petén-Itzá was funded by grants from the US National Science Foundation (ATM0502030), the International Continental Scientific Drilling Program, the Swiss Federal Institute of Technology, and the Swiss National Science Foundation. We are indebted to Anders Noren, Kristina Brady and Amy Myrbo of LacCore (National Lacustrine Core Facility), Department of Earth Sciences, University of Minnesota-Twin Cities for their expertise in core acquisition, curation and sampling. We are also very grateful towards D. Hodell, M. Brenner, J. Curtis, L. Perez, A. Schwalb, S. Kutterolf for providing material and data, R. Klee, V. Houk and P. Kociolek, for looking at specimens and encouraging 
PAILLÈS C. et al., New fossil genus and new extant species of Stephanodiscaceae (Guatemala)

this publication and L. Ector for providing extensive literature. SEM investigations were funded by the Institute for Research and Development (France). The Laboratoire Préparation Micropaléontologique (CEREGE, France) provided all facilities for sample processing. Finally, the constructive comments of two anonymous reviewers is gratefully acknowledged.

\section{References}

Àcs E., Ari E., Duleba M., Dressler M., Genkal S.I., Jako E., Rimet F., Ector L. \& Kiss K. 2016. Pantocseckiella, a new centric diatom genus based on morphological and genetic studies. Fottea 16 (1): 56-78. https://doi.org/10.5507/fot.2015.028

Alfinito S. \& Tagliaventi N. 2002. Morphology and taxonomy of Cyclotella elentarii spec. nova a newly described centric diatom from a New Zealand lake. Algological studies 105: 29-38.

https://doi.org/10.1127/algol_stud/105/2002/29

Anonymous. 1975. Proposals for standardization of diatom terminology and diagnoses. Beiheft zur Nova Hedwigia 53: 323-354.

Bedoshvili D. \& Likhoshway Y. 2019. Cellular mechanisms of diatom valve morphogenesis. In: Seckbach J. \& Gordon R. (eds) Diatoms: Fundamentals and Applications: 99-114. Scrivener Publishing, Austin. https://doi.org/10.1002/9781119370741.ch5

Benton M.J. \& Pearson P. 2001. Speciation in the fossil record. Trends in Ecology \& Evolution 16 (7): 405-411. https://doi.org/10.1016/S0169-5347(01)02149-8

Bradbury J.P. 1971. Paleolimnology of Lake Texcoco, Mexico. Evidence from diatoms. Limnology and Oceanography 16 (2): 180-200. https://doi.org/10.4319/lo.1971.16.2.0180

Bradbury J.P. 2000. Limnology history of Lago Pátzcuaro, Michoacàn, Mexico for the past 48,0000 years: impacts of the climate and man. Palaeogeography, Palaeoclimatology, Palaeoecology 163: 6995. https://doi.org/10.1016/S0031-0182(00)00146-2

Brébisson A. de 1838. Considérations sur les Diatomées et Essai d'une Classification des Genres et des Espèces appartenant à cette Famille. Brée l'Ainé Imprimeur-Librairie, Falaise.

https://doi.org/10.5962/bhl.title.64353

Chávez L. \& Haberyan K.A. 1996. Diatom assemblages from the Camastro diatomite, Costa Rica. Revista de Biologia tropical 44 (2): 899-902.

Cohuo S., Macario-González L., Pérez L., Sylvestre F., Paillès C., Curtis J.H., Kutterolf S., Wojewódka M., Zawisza E., Szeroczyńska K. \& Schwalb A. 2018. Climate ultrastructure and aquatic community response to Heinrich Stadials (HS5a-HS1) in the continental northern Neotropics. Quaternary Science Reviews 197: 75-91. https://doi.org/10.1016/j.quascirev.2018.07.015

Cvetkoska A., Hamilton P., Ognjanova-Rumenova N. \& Levkov Z. 2014. Observations of the genus Cyclotella (Kützing) Brébisson in ancient lakes Ohrid and Prespa and a descirption of two new species C. paraocellata sp. nov. and C. prespanensis sp. nov. Nova Hedwigia 98 (3-4): 313-340. https://doi.org/10.1127/0029-5035/2014/0154

Escobar J., Hodell D.A., Brenner M., Curtis J.H., Gilli A., Mueller A.D., Anselmetti F.S., Ariztegui D., Grzesik D.A., Perez L., Schwalb A. \& Guilderson T.P. 2012. A 43-ka record of paleoenvironmental change in the Central American lowlands inferred from stable isotopes of lacustrine ostracods. Quaternary Science Reviews 37: 92-104. https://doi.org/10.1016/j.quascirev.2012.01.020

Evans K.M., Chepurnov V.A., Sluiman H.J., Thomas S.J, Spears B.M. \& Mann D.G. 2009. Highly differentiated populations of the freshwater diatom Sellaphora capitata suggest limited dispersal and opportunities for allopatric speciation. Protist 160:386-396. https://doi.org/10.1016/j.protis.2009.02.001 
Genkal S.L. 1977. On counting of some taxonomically significant structural elements of valves in the diatom algae of the family Thalassiosiraceae Lebour emend. Hasle (Bacillariophyta). Botaničeskij žurnal 62 (6): 848-851. [In Russian.]

Glezer Z.I. \& Makarova I.V. 1986. Nouveaux ordres et familles de Diatomées (Bacillariophyta). Botaničeskij žurnal 71 (5): 673-676.

Guiry M.D. \& Guiry G.M. 2020. AlgaeBase. World-wide electronic publication, National University of Ireland, Galway. Available from http://www.algaebase.org [accessed 12 Jul. 2020].

Habeyran K.A. \& Horn S.P. 1999. A 10,000 years diatom record from a glacial lake in Costa Rica. Mountain Research and Development 19 (1): 63-70. https://doi.org/10.2307/3674114

Haberyan K.A. \& Horn S.P. 2005. Diatom paleoecology of Laguna Zoncho, Costa Rica. Journal of Paleolimnology 33 (3): 361-369. https://doi.org/10.1007/s10933-004-6789-4

Håkansson H. 1990. Cyclotella meneghiniana Kütz. (Bacillariophyceae), its morphology and reappraisal of similar species. Beiheft zur Nova Hedwigia 100: 19-37.

Håkansson H. 2002. A compilation and evaluation of species in the general Stephanodiscus, Cyclostephanos and Cyclotella with a new genus in the family Stephanodiscaceae. Diatom Research 17 (1): 1-139. https://doi.org/10.1080/0269249X.2002.9705534

Håkansson H., Hadju H., Snoeijs P. \& Loginova L. 1993. Cyclotella hakanssoniae Wendker, and its relationship to C. caspia Grunow and other similar brackish water Cyclotella species. Diatom Research 8: 333-347. https://doi.org/10.1080/0269249X.1993.9705266

Hodell D.A., Anselmetti F.S., Ariztegui D., Brenner M., Curtis J.H., Gilli A., Grzesik D.A., Guilderson T.J., Müller A.D., Bush M.B., Correa-Metrio A., Escobar J. \& Kutterolf S. 2008. An 85-ka record of climate in lowland Central America. Quaternary Science Reviews 27: 1152-1165.

https://doi.org/10.1016/j.quascirev.2008.02.008

Houk V., Klee R. \& Tanaka H. 2010. Atlas of freshwater centric diatoms with a brief key and descriptions. Part III. Stephanodiscaceae A, Cyclotella, Tertiarius, Discostella. Fottea 10 (supplement): 1-498.

Houk V., Klee R. \& Tanaka H. 2014. Atlas of freshwater centric diatoms with a brief key and descriptions. Part IV. Stephanodiscaceae B, Stephanodiscus, Cyclostephanos, Pliocaenicus, Hemistephanos, Stephanocostis, Mesodictyon \& Spicaticribra. Fottea 14 (supplement): 1-532.

Kaluzhnaya O. 2006. Valve morphogenesis in the centric diatom Cyclotella baicalensis. In: Likhosway Y. (ed.) Nineteenth International Diatom Symposium: 31-38. Biopress, Bristol.

Khursevich G. \& Kociolek J.P. 2012. A preliminary worldwide inventory of the extinct, freshwater fossil diatoms from the orders Thalassiosirales, Stephanodiscales, Paraliales, Aulacoseirales, Melosirales, Coscinodiscales and Biddulphiales. Beiheft zur Nova Hedwigia 141: 315-364.

Klee R. \& Houk V. 1996. Morphology and ultrastructure of Cyclotella woltereckii Hustedt (Bacillariophyceae). Archiv für Protistenkunde 147: 19-27.

https://doi.org/10.1016/S0003-9365(96)80005-4

Knapp J.M., Furey P.C. \& Lowe R.L. 2006. A comparison of the morphology and ultrastructure of the diatoms (Bacillaryophyceae) Discostella stelligera and D. elentarii from two lakes in Fiorland, New Zealand. New Zealand Journal of Marine and Freshwater Research 40: 429-438.

https://doi.org/10.1080/00288330.2006.9517433

Kociolek J.P. \& Khursevich G.H. 2013. Morphology of some lacustrine centric species from the western United States assigned to the genus Cyclotella (Bacillariophyta), including four described as new. Phytotaxa 127 (1): 81-99. https://doi.org/10.11646/phytotaxa.127.1.11 
PAILLÈS C. et al., New fossil genus and new extant species of Stephanodiscaceae (Guatemala)

Kociolek J.P., You Q., Stepanek J.G., Lowe R.L. \& Wang Q. 2016. New freshwater diatom genus, Edtheriotia gen. nov. of the Stephanodiscaceae (Bacillariophyta) from south-central China. Phycological Research 84: 274-280. https://doi.org/10.1111/pre.12145

Kociolek J.P., Balasubramanian K., Blanco S., Coste M., Ector L., Liu Y., Kulikovskiy M., Lundholm N., Ludwig T., Potapova M., Rimet F., Sabbe K., Sala S., Sar E., Taylor J., Van de Vijver B., Wetzel C.E., Williams D.M., Witkowski A. \& Witkowski J. 2018. DiatomBase. Discostella Houk \& Klee, 2004. Available from http://www.diatombase.org/aphia.php?p=taxdetails\&id=465545 [Accessed 19 Mar. 2020].

Krahn K., Wetzel C., Ector L. \& Schwalb A. 2018. Achnanthidium neotropicum sp.nov., a new freshwater diatom from lake Apastepeque in El Salvador (Central America). Phytotaxa 382 (1): 89-101. https://doi.org/10.11646/phytotaxa.382.1.4

Krammer K. \& Lange-Bertalot H. 1986. Bacillariophyceae. 1. Teil: Naviculaceae. In: Ettl H., Gerloff J., Heynig H. \& Mollenhauer D. (eds) Süßwasserflora von Mitteleuropa, Band 2/1: 1-876. Gustav Fischer Verlag, Stuttgart, Jena.

Krammer K. \& Lange-Bertalot H. 1988. Bacillariophyceae. 2. Teil: Bacillariaceae, Epithemiceae, Surirellaceae. In: Ettl H., Gerloff J., Heynig H. \& Mollenhauer D. (eds) Süßwasserflora von Mitteleuropa, Band 2/2: 1-596. Gustav Fischer Verlag, Stuttgart, Jena.

Krammer K. \& Lange-Bertalot H. 1991a. Bacillariophyceae. 3. Teil: Centrales, Fragilariaceae, Eunotiaceae. In: Ettl H., Gerloff J., Heynig H. \& Mollenhauer D. (eds) Süßwasserflora von Mitteleuropa, Band 2/3: 1-576. Gustav Fischer Verlag, Stuttgart, Jena.

Krammer K. \& Lange-Bertalot H. 1991b. Bacillariophyceae. 4. Teil: Achnanthaceae, Kritische Ergänzungen zu Navicula (Lineolatae) und Gomphonema, Gesamtliteraturverzeichnis Teil 1-4. In: Ettl H., Gerloff J., Heynig H. \& Mollenhauer D. (eds) Süßwasserflora von Mitteleuropa, Band 2/4: 1-437. Gustav Fischer Verlag, Stuttgart, Jena.

Kutterolf S., Schindlbeck J.C., Anselmetti F.S., Aritzegui D., Brenner M., Curtis J., Schmid D., Hodell D.A., Mueller A., Pérez L., Pérez W., Schwalb A., Frische M. \& Wang K.-L. 2016. A 400-ka tephrochronological framework for Central America from Lake Petén Itzá (Guatemala) sediments. Quaternary Science Reviews 150: 200-220. https://doi.org/10.1016/j.quascirev.2016.08.023

Lange C. \& Syversten E.E. 1989. Cyclotella litoralis sp. nov. (Bacillariophyceae) and its relationship to C. striata and C. stylorum. Nova Hedwigia 48 (3-4): 341-356.

Lange-Bertalot H. \& Metzeltin D. 2009. A dystrophic mountain lake in Panama - Hot spot of new and rare neotropical diatoms. Nova Hedwigia 135: 137-165.

Loginova L.P. 1990. Classification of the diatom genus Cyclotella. In: Simola H. (ed.) Proceedings of the $10^{\text {th }}$ international diatom symposium: 37-53. Koeltz Scientific Books, Koenigstein.

Lowe R.L. 1975. Comparative ultrastructure of the valves of some Cyclotella species (Bacillariophyceae). Journal of Phycology 11 (4): 415-424. https://doi.org/10.1111/j.1529-8817.1975.tb02805.x

McFarland B.H. \& Collins G.B. 1978. A key to the species of the diatom genus Cyclotella (Kütz.) Bréb. based on new morphological data. Abstract. In: $26^{\text {th }}$ annual meeting of North American Benthological Society: 35. Winnipeg.

Metcalfe S.E., O’Hara S.L., Caballero M. \& Davies S.J. 2000. Records of Late Pleistocene - Holocene climatic change in Mexico: a review. Quaternary Science Reviews 19: 699-721. https://doi.org/10.1016/S0277-3791(99)00022-0

Nakov T., Guillory W.X., Julius M.L., Theriot E.C. \& Alverson A.J. 2015. Towards a phylogenic classification of species belonging to the diatom genus Cyclotella (Baccilariophyceae): transfer of 
species formely placed in Puncticulata, Handmannia, Pliocaenicus and Cyclotella to the genus Lindavia. Phytotaxa 217 (3): 249-264. https://doi.org/10.11646/phytotaxa.217.3.2

Ortega B., Vàzquez G., Caballero M., Israde I., Lozano-Garcia S., Schaaf P. \& Torres E. 2010. Late Pleistocene: Holocene record of environmental changes in lake Zirahuen, Central Mexico. Journal of Paleolimnology 44: 745-760. https://doi.org/10.1007/s10933-010-9449-x

Paillès C., Sylvestre F., Escobar J., Tonetto A., Rustig S. \& Mazur J.C. 2018. Cyclotella petenensis and Cyclotella cassandrae, two new fossil diatoms from Pleistocene sediments of Lake Petén-Itzá, Guatemala, Central America. Phytotaxa 351 (4): 247-263. https://doi.org/10.11646/phytotaxa.351.4.1

Pérez L., Lorenschat J., Massaferro J., Paillès C., Sylvestre F., Hollwedel W., Brandorff G.-O., Brenner M., Islebe G., del Socorro Lozano M., Scharf B. \& Schwalb A. 2013. Bioindicators of climate and trophic status in aquatic ecosystems of the northern Neotropics. Revista de Biología Tropical 61 (2): 603-644. https://doi.org/10.15517/rbt.v61i2.11164

Prasad A.K.S.K \& Nienow A. 2006. The centric diatom genus Cyclotella (Stephanodiscaceae: Bacillariophyta) from Florida Bay, USA, with special reference to Cyclotella choctawhatcheeana and Cyclotella desikacharyi, a new marine species related to the Cyclotella striata complex. Phycologica 45 (2): $127-140$.

Rosenmeier M.F., Brenner M., Kenney W.F., Whitmore T.J. \& Taylor C.M. 2004. Recent eutrophication in the southern basin of Lake Petén Itzá, Guatemala: human impact on a large tropical lake. Hydrobiologia 511 (1-3): 161-172. https://doi.org/10.1023/B:HYDR.0000014038.64403.4d

Ross R., Cox E.J., Karayeva N.I., Mann D.G., Paddock T.B.B., Simonsen R. \& Sims P.A. 1979. An amended terminology for the siliceous components of the diatom cell. Beiheft zur Nova Hedwigia 64: $513-533$.

Round F.E., Crawford R.M. \& Mann D.G. 1990. The Diatoms. Biology and Morphology of the Genera. Cambridge University Press, Cambridge.

Serieyssol K. 1981. Cyclotella species of Late Miocene from St. Bauzile, France. In: Ross R. (ed.) Proceedings of the $6^{\text {th }}$ International Diatom Symposium: 27-42. Koeltz Scientific Books, Koenigstein.

Servant-Vildary S. 1986. Fossil Cyclotella species from Miocene deposits of Spain. In: Ricard M. (ed.) Proceedings of the $8^{\text {th }}$ International Diatom Symposium: 495-511. Otto Koeltz, Koenigstein.

Slate J.E., Jonson T.C. \& Moore T.C. 2013. Impact of pre-Columbian agriculture, climate change, and tectonic activity inferred from a 5,700-years paleolimnological record from lake Nicaragua. Journal of Paleolimnology 50: 139-149. https://doi.org/10.1007/s10933-013-9709-7

Tagliaventi N. \& Cavacini P. 2002. A study on the morphology of Cyclotella areolata Hustedt, C. stelligera Cleve et Grunow var. robusta and C. stelligera Cleve et Grunow var. hyalina Hustedt, using original material. Algological studies 107: 1-16. https://doi.org/10.1127/algol_stud/107/2002/1

Tanaka H. 2007. Taxonomic studies of the genera Cyclotella (Kützing) Brébisson, Discostella Houk et Klee and Puncticulata Håkansson in the family Stephanodiscaceae Glezer et Makarova (Bacillariophyta) in Japan. Bibliotheca Diatomologica 53: 1-204.

Temoltzin-Loranca Y., Velez M.I., Moreno E. \& Escobar J. 2018. Late Holocene environmental change in Lake Boquete and its watershed: human or natural causes? Boletín de la Sociedad Geológica Mexicana 70 (1): 121-131. https://doi.org/10.18268/BSGM2018v70n1a7

Theriot E.C., Håkansson H., Kociolek J.P., Round F.E. \& Stoermer E.F. 1987. Validation of the centric diatom genus name Cyclostephanos. British Phycological Journal 22: 345-347.

https://doi.org/10.1080/00071618700650411 
PAILLÈS C. et al., New fossil genus and new extant species of Stephanodiscaceae (Guatemala)

Theriot E. \& Serieyssol K. 1994. Phylogenic systematics as a guide to understanding features and potential morphological characters of the centric diatoms family Thalassiosiraceace. Diatom Research 9 (2): 429-450. https://doi.org/10.1080/0269249X.1994.9705318

Theriot E.C., Fritz S.C, Whitlock C. \& Conley D. 2006. Late Quaternary rapid morphological evolution of an endemic diatom in Yellowstone Lake, Wyoming. Paleobiology 32 (1): 38-54.

https://doi.org/10.1666/0094-8373(2006)032[0038:LQRMEO]2.0.CO;2

Wetzel C.E. \& Ector L. 2014. Planothidium lagerheimii comb. nov. (Bacillariophyta, Achnanthales) a forgotten diatom from South America. Phytotaxa 188 (5): 261-267.

https://doi.org/10.11646/phytotaxa.188.5.3

Whitmore T.J., Brenner M., Curtis J.H., Dahlin B.H. \& Leyden B.W. 1996. Holocene climate and human influences on lakes of the Yucatan Peninsula Mexico: an interdisciplinary, palaeolimnological approach.

The Holocene 6: 273-287. https://doi.org/10.1177/095968369600600303

Manuscript received: 6 April 2020

Manuscript accepted: 24 September 2020

Published on: 30 November 2020

Topic editor: Christian de Muizon

Desk editor: Radka Rosenbaumová

Printed versions of all papers are also deposited in the libraries of the institutes that are members of the EJT consortium: Muséum national d'histoire naturelle, Paris, France; Meise Botanic Garden, Belgium; Royal Museum for Central Africa, Tervuren, Belgium; Royal Belgian Institute of Natural Sciences, Brussels, Belgium; Natural History Museum of Denmark, Copenhagen, Denmark; Naturalis Biodiversity Center, Leiden, the Netherlands; Museo Nacional de Ciencias Naturales-CSIC, Madrid, Spain; Real Jardín Botánico de Madrid CSIC, Spain; Zoological Research Museum Alexander Koenig, Bonn, Germany; National Museum, Prague, Czech Republic. 